\title{
Selective Reduction of NOx by Propylene Over Silver Catalyst Under Oxidative Conditions
}

\author{
Julia María D. Cónsul, Daniel Thiele, Ione M. Baibich* and Renato C. Veses \\ Instituto de Química, Universidade Federal do Rio Grande do Sul, Avenida Bento Gonçalves, 9500, \\ 91501-970 Porto Alegre - RS, Brazil
}

\begin{abstract}
Neste trabalho foram estudados catalisadores $\mathrm{Ag} / \mathrm{Al}_{2} \mathrm{O}_{3}$ e $\mathrm{Ag} / \mathrm{Al}_{2} \mathrm{O}_{3} /$ Corderita, preparados por um método de impregnação convencional, na reação de redução de NO utilizando propeno como agente redutor. Os catalisadores foram caracterizados por redução a temperatura programada (RTP), quimissorção de oxigênio e área superficial, pelo método BET. A atividade catalítica foi determinada utilizando uma mistura reacional contendo $100 \mathrm{ppm}$ de $\mathrm{NO}, 250 \mathrm{ppm}$ de $\mathrm{C}_{3} \mathrm{H}_{6}$ e $2 \%$ de oxigênio e uma velocidade espacial de $100000 \mathrm{~h}^{-1}$. Os produtos da reação foram estudados por FTIR. Os resultados dos testes catalíticos mostraram $56 \%$ de conversão de NO para o catalisador $2,22 \% \mathrm{Ag} /$ $\mathrm{Al}_{2} \mathrm{O}_{3}$ a $723 \mathrm{~K}$. Os catalisadores de cordierita apresentaram um comportamento semelhante, mas a temperatura de máxima conversão de $\mathrm{NO}$ deslocou-se para temperaturas menores.
\end{abstract}

In this study, a $\mathrm{Ag} / \mathrm{Al}_{2} \mathrm{O}_{3}$ and $\mathrm{Ag} / \mathrm{Al}_{2} \mathrm{O}_{3} /$ Cordierite catalyst was prepared by a conventional impregnation method and NOx reduction investigated using propylene as a reducing agent. The catalysts were characterized by Temperature Programmed Reduction (TPR), oxygen chemisorption and surface area, using the standard BET method. The catalytic activities were measured under the same reaction conditions, i.e., $100 \mathrm{ppm} \mathrm{NO}, 250 \mathrm{ppm} \mathrm{C}_{3} \mathrm{H}_{6}, 2 \%$ of oxygen and $100000 \mathrm{~h}^{-1}$ space velocity. The reaction products were analyzed by FTIR. The results of the catalytic activity obtained for the $2.22 \% \mathrm{Ag} / \mathrm{Al}_{2} \mathrm{O}_{3}$ catalyst showed $56 \% \mathrm{NO}$ conversion at $723 \mathrm{~K}$. The catalysts based on Cordierite presented an analogous behavior, but the temperature of maximum NO conversion was lower $(620 \mathrm{~K})$.

Keywords: NOx reduction, silver/alumina catalyst, propylene, Cordierite

\section{Introduction}

The generation of NOx effluents from stationary and mobile sources poses an important environmental problem..$^{1-4}$ Gas effluent control in internal combustion engines, whose air/gasoline ratio is stoichiometric, can be achieved by using the so-called "three way catalysts" (TWC) typically containing Pt and Rh as the active metals. On the other hand, lean-burn engines, such as diesel engines and stationary sources for industrial use, operate with excess oxygen to ensure complete combustion. In these cases, TWCs are ineffective for NO elimination, for which reason selective catalytic reduction ( $\mathrm{SCR}$ ) is used. A typical commercial SCR catalyst use $\mathrm{V}_{2} \mathrm{O}_{5}-\mathrm{WO}_{3}-\mathrm{TiO}_{2}$ as the metal system and $\mathrm{NH}_{3}$ as the reducing agent. This catalyst involves problems relating to the transport and storage of $\mathrm{NH}_{3}$ and to vanadium toxicity. ${ }^{5}$ In their studies of several catalysts prepared from zeolites substituted with

\footnotetext{
* e-mail: ione@iq.ufrgs.br
}

$\mathrm{H}^{+}, \mathrm{Na}^{+}, \mathrm{K}^{+}, \mathrm{Mg}^{2+}, \mathrm{Ca}^{2+}, \mathrm{Cr}^{3+}, \mathrm{Fe}^{3+}, \mathrm{Co}^{3+}, \mathrm{Ni}^{2+}, \mathrm{Cu}^{2+}, \mathrm{Zn}^{2+}$ and $\mathrm{Ag}$, Iwamoto et al. ${ }^{6,7}$ found that $\mathrm{Cu}-\mathrm{ZSM} 5$ provided better NO reduction activity when hydrocarbons were used as reductants. However, this catalyst has a low thermal stability $^{6}$ and deactivates in the presence of water vapor and $\mathrm{SO}_{2}$. Moreover, large amounts of water vapor inhibit the catalyst's action, promoting the migration of $\mathrm{Al}^{+3}$ out of the zeolite structure and leading to a loss of the activity of the $\mathrm{Cu}$ ions attached to the $\mathrm{Al}$ sites. ${ }^{8}$

Platinum SCR catalysts are very active at low temperatures, and are thermally stable and resistant to $\mathrm{SO}_{2}$. Obuchi and co-workers ${ }^{9}$ studied the SCR reaction in the presence of propylene with $\mathrm{Pt}, \mathrm{Ir}, \mathrm{Pd}, \mathrm{Rh}$ and $\mathrm{Ru}$ metals based on $\gamma$-alumina, obtaining the best results with the metals Pt, Rh and Ru, with NO conversions of over $50 \%$. The selectivity for $\mathrm{N}_{2}$ was better with $\mathrm{Rh}$ (more than $90 \%$ of consumed $\mathrm{NO}$ was converted into $\mathrm{N}_{2}$ ). In contrast, platinum was not as selective, i.e., only $2 / 3$ of the NO consumed was transformed into $\mathrm{N}_{2} \mathrm{O}$. Silver catalysts supported on alumina, with unsaturated and partially 
oxidized hydrocarbons as reductants, have recently been used for NO reduction, presenting conversions that might justify their commercial use. ${ }^{10-13}$

Ceramic materials are often used as a "primary" support, especially Cordierite $\left(2 \mathrm{MgO} .2 \mathrm{Al}_{2} \mathrm{O}_{3} \cdot 5 \mathrm{SiO}_{2}\right)$. High temperatures are tolerable with the use of Cordierite. In addition, ceramic materials have a relatively high melting point and excellent thermal shock resistance. Since Cordierite possesses a low surface area and the catalytically active component is supported on the high surface area material, $\gamma$-alumina is the most commonly used. ${ }^{14}$ In this way, alumina-coated Cordierite is an interesting support for environmental catalysts.

This paper reports on the results found for catalysts prepared from Ag on alumina and alumina-coated Cordierite in the NO reduction reaction, using propylene as the reducing agent. The effect of particle size on the activity is also discussed.

\section{Experimental}

The silver catalysts were prepared by incipient wetness impregnation of $\mathrm{AgNO}_{3}$ (Merck 99.8\%) on alumina (Condea, $210 \mathrm{~m}^{2} / \mathrm{g}$ ) or alumina-coated Cordierite prepared as follows. Alumina (Condea) was used in the form of particles with diameters ranging from 0.25 to $0.42 \mathrm{~mm}$. The Alumina/Cordierite support was obtained by impregnating the $0.25-0.42 \mathrm{~mm}$ diameter Cordierite particles with a $4 \%$ weight $\mathrm{Al}(\mathrm{OH})_{3}$ solution $(\mathrm{pH} 4.5$ with $\mathrm{HNO}_{3}$ ). After impregnation, the support was dried at $383 \mathrm{~K}$ for $4 \mathrm{~h}$ and calcined at $623 \mathrm{~K}$ for $2 \mathrm{~h}$. The process was repeated ten times, resulting in a support with $7 \%$ weight $\mathrm{Al}_{2} \mathrm{O}_{3}$ on the Cordierite surface. Metal loads were determined by AAS.

The catalytic tests were conducted in a fixed-bed quartz flow reactor with a space velocity of $100000 \mathrm{~h}^{-1}$ and a total gas flow (100 ppm NO, $250 \mathrm{ppm}$ propylene and $2 \%$ oxygen in $\mathrm{He}$ ) of $155 \mathrm{~cm}^{3} \mathrm{~min}^{-1}$. The reactor's effluent gases were analyzed by FTIR (BOMEM, MB100 model) equipped with a $2 \mathrm{~L}$ gas cell (optical length $=2.4 \mathrm{~m}$ ). The $\mathrm{NO}, \mathrm{N}_{2} \mathrm{O}$ and $\mathrm{C}_{3} \mathrm{H}_{6}$ concentrations were measured by integrating the peaks in selected regions of its absorbance spectrum (1955 - 1879.5, 2262.3 - 2242.7 and 928.84 - $897.9 \mathrm{~cm}^{-1}$, respectively) and comparing these to a calibration curve.

Catalysts characterization were performed by temperature-programmed reduction (TPR), raising the temperature to $793 \mathrm{~K}$ at a rate of $10 \mathrm{~K} \mathrm{~min}^{-1}$. During the measurements, $5 \% \mathrm{H}_{2} / \mathrm{Ar}$ was introduced into the reactor at a flow rate of $15 \mathrm{~cm}^{3} \mathrm{~min}^{-1}$. Oxygen chemisorption measurements were taken by the pulse technique, using a Thermal Conductivity Detector (TCD) at $443 \mathrm{~K}$, the optimum temperature for oxygen adsorption on silver particles. The dispersions were calculated assuming a stoichiometry of unity for the O/Ag ratio. ${ }^{15,16}$ The catalysts specific surface areas were measured using the BET technique in a volumetric apparatus. The catalysts were dried at $423 \mathrm{~K}$ for $1 \mathrm{~h}$ before their characterization, which was based on the physical adsorption of nitrogen $\left(\mathrm{N}_{2}\right)$ at the liquid nitrogen temperature $(77 \mathrm{~K})$. Data are the average of three measurements.

\section{Results and Discussion}

\section{Catalysts characterization}

Table 1 summarizes the results of dispersion $(\gamma)$, particle diameter (d) and metallic surface area (Am) obtained by oxygen chemisorption measurements.

Table 1. Parameters obtained by oxygen chemisorption measurements

\begin{tabular}{lccc}
\hline Sample & $\begin{array}{c}\gamma \\
(\%)\end{array}$ & $\begin{array}{c}\mathrm{Am} \\
\left(\mathrm{m}^{2} \mathrm{~g}^{-1} \text { cat }\right)\end{array}$ & $\begin{array}{c}\mathrm{d} \\
(\mathrm{nm})\end{array}$ \\
\hline $0.8 \% \mathrm{Ag} / \mathrm{Al}_{2} \mathrm{O}_{3}$ & 4 & 0.2 & 29 \\
$2.2 \% \mathrm{Ag} / \mathrm{Al}_{2} \mathrm{O}_{3}$ & 16 & 1.8 & 7 \\
$3.8 \% \mathrm{Ag} / \mathrm{Al}_{2} \mathrm{O}_{3}$ & 6 & 1.1 & 20 \\
$7.6 \% \mathrm{Ag} / \mathrm{A} \mathrm{Al}_{2} \mathrm{O}_{3}$ & 2 & 0.8 & 56 \\
$2.5 \% \mathrm{Ag} / \mathrm{Al}_{2} \mathrm{O}_{3} /$ Cord & 2 & 0.3 & 48 \\
$0.12 \% \mathrm{Ag} / \mathrm{Al}_{2} \mathrm{O}_{3} /$ Cord & 7 & 0.1 & 12 \\
\hline
\end{tabular}

The increase of metal loads was found to cause agglomeration of $\mathrm{Ag}$ particles and a consequent decrease in dispersion and exposed metal area as expected.

A comparison of the Ag/alumina catalysts in Figure 1 shows that the maximum Ag surface area was obtained for the $2 \% \mathrm{Ag}$ catalyst and decreased with higher metal contents, as a result of particle agglomeration, causing the dispersion values to decrease and the particle diameters to increase. The $0.8 \% \mathrm{Ag} / \mathrm{Al}_{2} \mathrm{O}_{3}$ catalyst showed a different behavior. The low silver concentration supported on the alumina's high surface area probably generated a stable

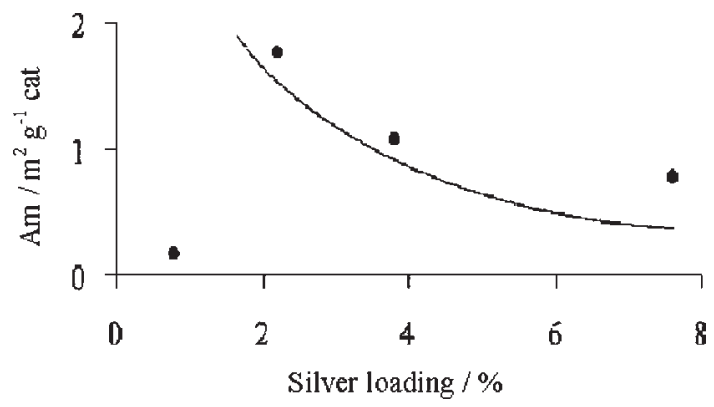

Figure 1. Effect of Ag loads on the metallic surface. 
phase with alumina, that did not adsorb oxygen at $443 \mathrm{~K}$ (chemisorption measurements temperature). Based on their XRD analysis of $\mathrm{Cu}, \mathrm{Ni}$ and $\mathrm{Co} / \mathrm{Al}_{2} \mathrm{O}_{3}$, Shimizu et al. ${ }^{17}$ confirmed the formation of an aluminate phase and concluded that this phase was responsible for the activity and selectivity of the catalysts studied. Miyadera ${ }^{13}$ also mentioned that the interaction between $\mathrm{Ag}$ and alumina support is important to inhibit the deactivation caused by the reduction of the oxidized Ag species during the reaction. Nakatsuji et $a l^{18}$ showed that a low loading catalyst displayed oxidic species of silver, possibly as an aluminate.

The catalyst prepared on alumina-coated Cordierite with a $2.5 \%$ silver load presented $2 \%$ dispersion, a metallic surface area of $0.3 \mathrm{~m}^{2} \mathrm{~g}^{-1}$ and large particles. The values found were analogous to the $7.6 \% \mathrm{Ag} / \mathrm{Al}_{2} \mathrm{O}_{3}$ catalyst. Assuming that Cordierite contains $7 \%$ wt. of alumina and that all the Cordierite is perfectly coated with alumina, the $\mathrm{Ag}$ content would be greater than $30 \%$, leading to very large particles. Therefore, the $0.12 \% \mathrm{Ag} / \mathrm{Al}_{2} \mathrm{O}_{3} /$ Cord catalyst was prepared to contain the same ratio of metal atoms on the alumina covering the Cordierite as the $2.2 \% \mathrm{Ag} / \mathrm{Al}_{2} \mathrm{O}_{3}$ catalyst. However, it did not present the same characteristics; instead, the chemisorption parameters decreased (dispersion and metallic surface area) or increased (particle diameter) twofold. In this case, the Cordierite was probably not perfectly coated with the alumina and part of silver particles were deposited on the surface cavities. SEM (scanning electron microscopy) analysis (Figure 2) revealed that the surface $\mathrm{Al}_{2} \mathrm{O}_{3} /$ Cord support presented cavities. These are several parameters that have to be controlled to obtain a homogeneous alumina coated film. Even so, cavities are often found. ${ }^{14,19-21}$

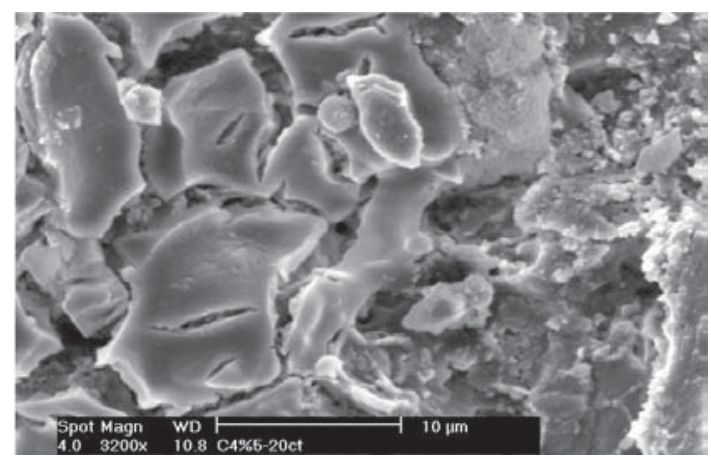

Figure 2. SEM micrograph of the $\mathrm{Al}_{2} \mathrm{O}_{3}$ /Cordierite support.

Figure 3 depicts the TPR profiles for the $0.8 \%, 2.2 \%$ and $3.8 \%$ silver catalysts on alumina, showing two peaks for $\mathrm{H}_{2}$ uptake. As the metal content increased, the two signals shifted to low temperatures, suggesting that, with

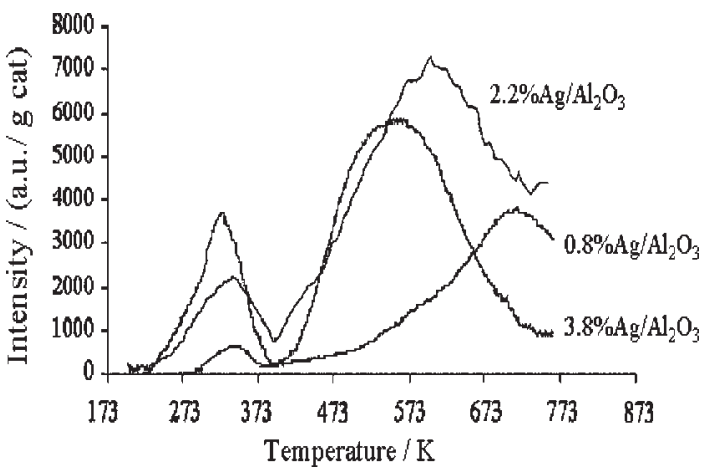

Figure 3. TPR profiles of the $0.8,2.2$ and $3.8 \% \mathrm{Ag} / \mathrm{Al}_{2} \mathrm{O}_{3}$ catalysts.

the increase in particle size and resulting decrease in dispersion, the interaction between the particles and the support became weaker, leading to lower temperatures for metal reduction. Furthermore, the first peak intensity rose with the increase in $\mathrm{Ag}_{2} \mathrm{O}$ particles, which became easily reducible, in agreement with Bethke and Kung, ${ }^{10}$ who observed two peaks for 2 and $6 \% \mathrm{Ag} / \mathrm{Al}_{2} \mathrm{O}_{3}$ catalysts. The low temperature peaks were attributed to the reduction of large $\mathrm{Ag}_{2} \mathrm{O}$ clusters interacting weakly with the support, which typically are easier to reduce than small metal oxide particles. The second peak of the $0.8 \% \mathrm{Ag} / \mathrm{Al}_{2} \mathrm{O}_{3}$ catalyst with low metal contents was located at a high temperature and its intensity was low, confirming our assumption that, in this case, there was strong interaction with the support, which led to a very stable Ag phase with low reductibility of the species.

The TPR profiles for the $7.6 \% \mathrm{Ag} / \mathrm{Al}_{2} \mathrm{O}_{3}, 0.12 \% \mathrm{Al}_{2} \mathrm{O}_{3} /$ Cord and $2.5 \% \mathrm{Ag} / \mathrm{Al}_{2} \mathrm{O}_{3} /$ Cord catalysts are shown together in Figure 4 for the sake of comparison, since their chemisorption data are similar. The two temperature peaks of the $2.5 \% \mathrm{Ag} / \mathrm{Al}_{2} \mathrm{O}_{3} /$ Cord catalyst were very close (around $383 \mathrm{~K}$ and $493 \mathrm{~K}$ ), suggesting that the metal species on the support had similar characteristics. The first peak at $383 \mathrm{~K}$ may be attributed to $\mathrm{Ag}_{2} \mathrm{O}$ particles interacting weakly

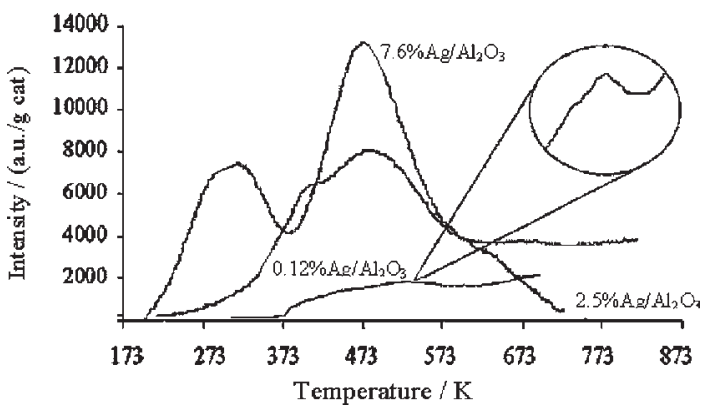

Figure 4. TPR profile of $7.6 \% \mathrm{Ag} / \mathrm{Al}_{2} \mathrm{O}_{3}, 0.21 \% \mathrm{Ag} / \mathrm{Al}_{2} \mathrm{O}_{3} /$ Cord and $2.5 \% \mathrm{Ag} / \mathrm{Al}_{2} \mathrm{O}_{3} /$ Cord catalysts. 
with the support, although this interaction was stronger than that of the same particles of the $7.6 \% \mathrm{Ag} / \mathrm{Al}_{2} \mathrm{O}_{3}$ catalyst, as a result of different particle diameters, according to the oxygen chemisorption results. On the other hand, the second peak at a higher temperature $(493 \mathrm{~K})$ may be ascribed to similar species found in the $7.6 \% \mathrm{Ag} / \mathrm{Al}_{2} \mathrm{O}_{3}$ catalyst. The same peaks were observed in the $0.12 \% \mathrm{Ag} /$ $\mathrm{Al}_{2} \mathrm{O}_{3}$ /Cord catalyst but, in this case, they shifted to high temperatures ( $453 \mathrm{~K}$ and $564 \mathrm{~K}$ ), suggesting a stronger interaction with the support than the other catalysts.

Table 2 presents the surface area of the catalysts. In general, alumina supports caused the surface area to decrease slightly as the silver concentration increased, suggesting that higher metallic particle sizes led to a blockage of the alumina pores, decreasing the surface area. On the other hand, the $\mathrm{Al}_{2} \mathrm{O}_{3}$ /Cord support displayed a much higher surface area than the Cordierite, demonstrating that alumina deposition efficiently promoted an increase of the very small Cordierite surface area. The $2.5 \% \mathrm{Ag} /$ $\mathrm{Al}_{2} \mathrm{O}_{3}$ /Cord catalyst also showed a surface area decrease.

Table 2. BET surface area

\begin{tabular}{lc}
\hline Catalysts & BET surface area $\left(\mathrm{m}^{2} \mathrm{~g}^{-1}\right)$ \\
\hline $0.8 \% \mathrm{Ag} / \mathrm{Al}_{2} \mathrm{O}_{3}$ & $205 \pm 0.2$ \\
$2.2 \% \mathrm{Ag} / \mathrm{Al}_{2} \mathrm{O}_{3}$ & $195 \pm 6.5$ \\
$3.8 \% \mathrm{Ag} / \mathrm{Al}_{2} \mathrm{O}_{3}$ & $190 \pm 5.6$ \\
$7.6 \% \mathrm{Ag} / \mathrm{A} \mathrm{Al}_{2} \mathrm{O}_{3}$ & $185 \pm 5.2$ \\
$2.5 \% \mathrm{Ag} / \mathrm{Al}_{2} \mathrm{O}_{3} /$ Cord & $16 \pm 0.3$ \\
$0.12 \% \mathrm{Ag} / \mathrm{Al}_{2} \mathrm{O}_{3} /$ Cord & $26 \pm 0.2$ \\
Cordierite & $1 \pm 0.0$ \\
$\mathrm{Al}_{2} \mathrm{O}_{3} /$ Cordierite & $27 \pm 0.0$ \\
\hline
\end{tabular}

\section{Conversion tests versus temperature}

Figure 5 shows the conversions for the propylene oxidation and $\mathrm{NO}$ reduction reactions for $0.8 \% \mathrm{Ag} / \mathrm{Al}_{2} \mathrm{O}_{3}$ and $2.2 \% \mathrm{Ag} / \mathrm{Al}_{2} \mathrm{O}_{3}$ in the $373-873 \mathrm{~K}$ temperature range. Both catalysts can be seen to be active for NO reduction in the range of $673 \mathrm{~K}$ to $773 \mathrm{~K}$, decreasing at higher temperatures. The propylene oxidation reaction revealed a different behavior: the conversion increased until total propylene conversion was reached. Both catalysts produced similar results for NO reduction, but the $2.2 \% \mathrm{Ag} /$ $\mathrm{Al}_{2} \mathrm{O}_{3}$ catalyst showed higher propylene oxidation conversions at temperatures where NO reduction conversions were higher. Figure 6 presents the results of both reactions results for the catalysts with higher silver concentrations. A comparison of Figures 6 and 5 indicate that higher metal loads led to lower temperatures for maximum hydrocarbon conversions, with the $7.6 \% \mathrm{Ag} /$ $\mathrm{Al}_{2} \mathrm{O}_{3}$ catalyst presenting the lowest temperature. This

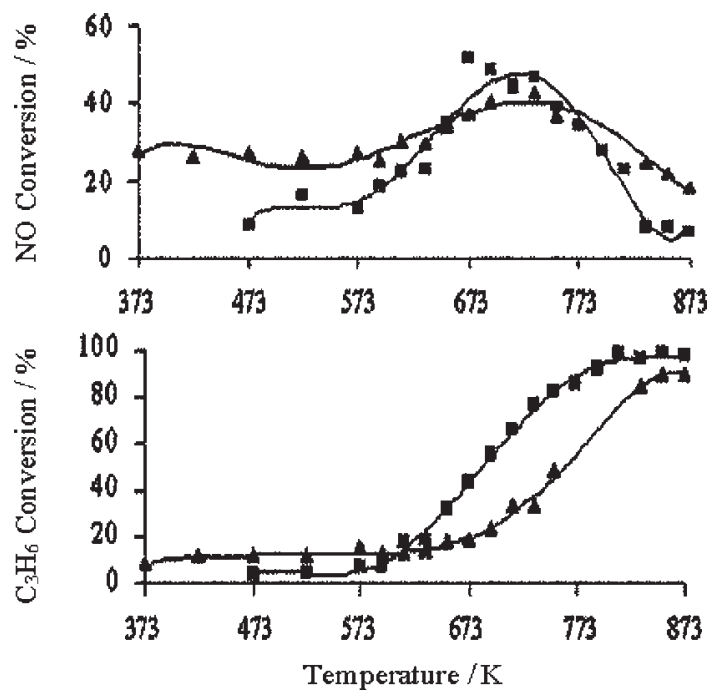

Figure 5. NO and propylene conversions vs. temperature for the catalysts $(\boldsymbol{\Delta}) 0.8 \% \mathrm{Ag} / \mathrm{Al}_{2} \mathrm{O}_{3},(\boldsymbol{\square}) 2.2 \% \mathrm{Ag} / \mathrm{Al}_{2} \mathrm{O}_{3}$. (100 ppm $\mathrm{NO}+$ $\left.250 \mathrm{ppm} \mathrm{C}_{3} \mathrm{H}_{6}+2 \% \mathrm{O}_{2}+\mathrm{He}\right) .100000 \mathrm{~h}^{-1}$.

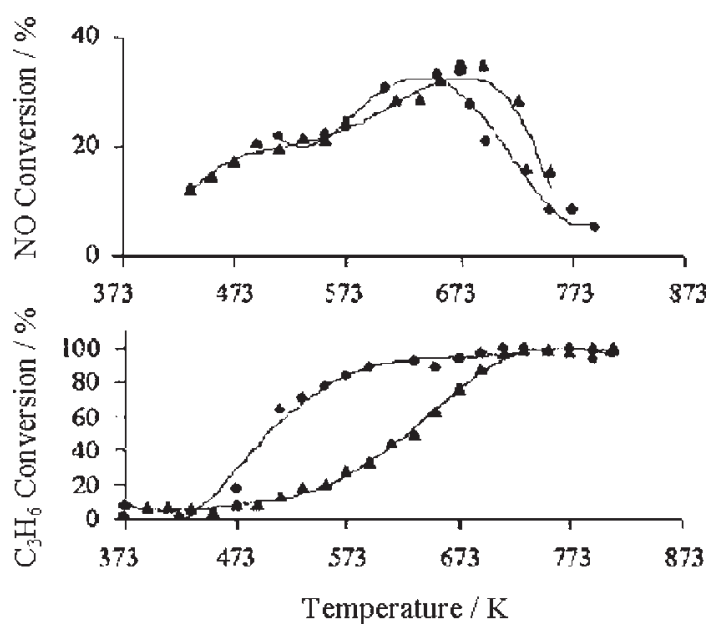

Figure 6. NO and propylene conversions vs. temperature for the catalysts $(\boldsymbol{\Delta}) 3.8 \% \mathrm{Ag} / \mathrm{Al}_{2} \mathrm{O}_{3}$ and $(\bullet) 7.6 \% \mathrm{Ag} / \mathrm{Al}_{2} \mathrm{O}_{3}$. $(100 \mathrm{ppm} \mathrm{NO}+$ $\left.250 \mathrm{ppm} \mathrm{C}_{3} \mathrm{H}_{6}+2 \% \mathrm{O}_{2}+\mathrm{He}\right) .100000 \mathrm{~h}^{-1}$.

effect may be due to the presence of larger particles, which favor oxygen and propylene adsorption on the same active particle; hence, the propylene oxidation is more effective than the NO reduction. These results are in accord to other authors, ${ }^{10,22-25}$ that found a relationship between particle size, oxidation state and catalytic activities.

If one considers the correlation between $\mathrm{NO}$ conversion at $673 \mathrm{~K}$ and $\mathrm{Ag}$ dispersion values (Figure 7), one finds that the maximum NO conversion was obtained for the catalyst with the highest dispersion, indicating that there 


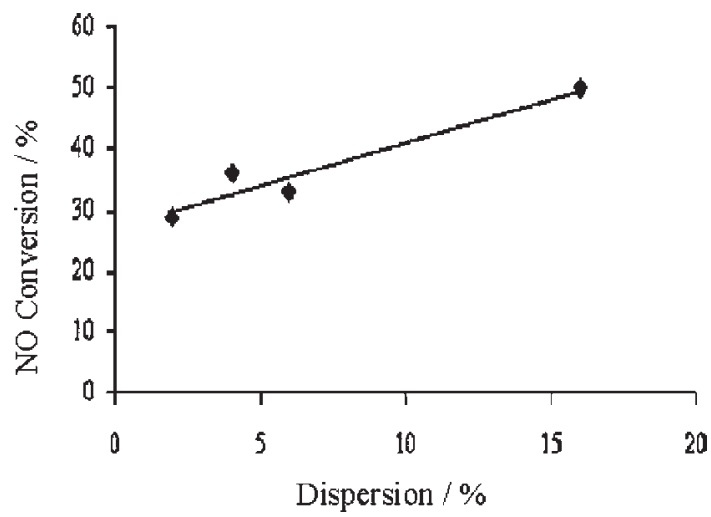

Figure 7. Correlation between NO conversions and dispersion values for the alumina-based catalysts at $673 \mathrm{~K}$.

is an optimum particle size at which the NO reduction reaction is effective in the presence of propylene and excess oxygen.

Figure 8 shows conversion tests versus temperature for the $2.5 \% \mathrm{Ag} / \mathrm{Al}_{2} \mathrm{O}_{3} /$ Cord and $0.12 \% \mathrm{Ag} / \mathrm{Al}_{2} \mathrm{O}_{3} / \mathrm{Cord}$ catalysts. The NO conversion behavior was analogous to that of the alumina-based catalysts, but the maximum NO conversions occurred at lower temperatures than with the latter catalysts. In the case of the $2.5 \% \mathrm{Ag} / \mathrm{Al}_{2} \mathrm{O}_{3} / \mathrm{Cord}$, this may be evidence that there is around $30 \%$ of metal on the alumina, as explained earlier, leading to lower temperatures than for the highest metal concentration alumina-based catalyst $\left(7.6 \% \mathrm{Ag} / \mathrm{Al}_{2} \mathrm{O}_{3}\right)$, which confirms the effect of the metal concentration on the reaction temperature. The maximum effective conversion for this catalyst is the

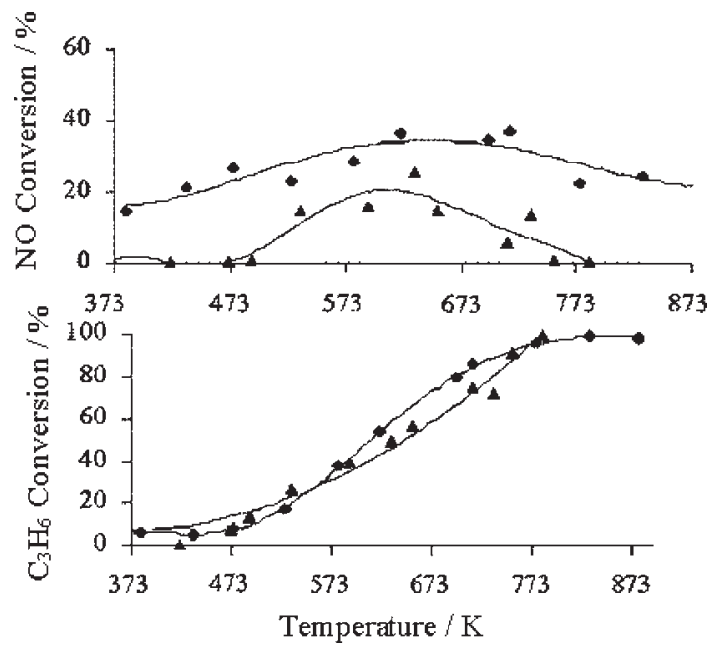

Figure 8. NO and propylene conversions vs. temperature for the

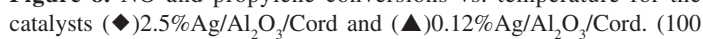
ppm $\left.\mathrm{NO}+250 \mathrm{ppm} \mathrm{C}_{3} \mathrm{H}_{6}+2 \% \mathrm{O}_{2}+\mathrm{He}\right) .100000 \mathrm{~h}^{-1}$. highest one, considering that the exposed metal surface area of this catalyst $\left(0.29 \mathrm{~m}^{2} \mathrm{~g}^{-1}\right.$ cat $)$ is much lower than the $2.2 \% \mathrm{Ag} / \mathrm{Al}_{2} \mathrm{O}_{3}$ one $\left(1.76 \mathrm{~m}^{2} \mathrm{~g}^{-1} \mathrm{cat}\right)$ even with similar $\mathrm{Ag}$ loads. Plummer et al. ${ }^{26}$ investigated a similar catalyst $(0.3-$ $0.8 \% \mathrm{Ag} / \mathrm{Al}_{2} \mathrm{O}_{3} /$ Cord) for the oxidation of methanol, obtaining conversions of up to $90 \%$.

Although we expected the NO conversion of the $0.12 \% \mathrm{Ag} / \mathrm{Al}_{2} \mathrm{O}_{3} / \mathrm{Cord}$ to be similar to that of the $0.8 \% \mathrm{Ag} /$ $\mathrm{Al}_{2} \mathrm{O}_{3}$ catalyst, it was lower than the latter. In this case, the $0.12 \% \mathrm{Ag} / \mathrm{Al}_{2} \mathrm{O}_{3} /$ Cord catalyst had a lower silver load than $0.8 \% \mathrm{Ag} / \mathrm{Al}_{2} \mathrm{O}_{3}$ catalyst and, as explained earlier, the alumina/Cordierite support have cavities; therefore, possibly part of the silver particles were deposited inside these cavities, preventing them from participating in the SCR reaction.

\section{Conversion tests versus time}

Table 3 shows the $\mathrm{NO}$ and $\mathrm{C}_{3} \mathrm{H}_{6}$ conversions after a 150 min test period at the maximum $\mathrm{NO}$ conversion temperature for the Ag/alumina catalyst. During the $\mathrm{C}_{3} \mathrm{H}_{6}-\mathrm{SCR}$ of NO, the NO and propylene conversions remained at approximately the values reported in Table 3 in each time interval.

Table 3. Maximum $\mathrm{NO}$ and $\mathrm{C}_{3} \mathrm{H}_{6}$ conversion for the Ag/alumina catalyst at the maximum $\mathrm{NO}$ conversion temperature

\begin{tabular}{lccc}
\hline Catalysts & $\begin{array}{c}\mathrm{NO} \\
\text { conversions } \\
(\%)\end{array}$ & $\begin{array}{c}\mathrm{C}_{3} \mathrm{H}_{6} \\
\text { conversions } \\
(\%)\end{array}$ & $\begin{array}{c}\text { Maxima NO } \\
\text { conversion } \\
\text { temperatures (K) }\end{array}$ \\
\hline $0.8 \% \mathrm{Ag} / \mathrm{Al}_{2} \mathrm{O}_{3}$ & 40 & 35 & 713 \\
$2.2 \% \mathrm{Ag} / \mathrm{Al}_{2} \mathrm{O}_{3}$ & 50 & 70 & 723 \\
$3.8 \% \mathrm{Ag} / \mathrm{Al}_{2} \mathrm{O}_{3}$ & 30 & 95 & 695 \\
$7.6 \% \mathrm{Ag} / \mathrm{A} \mathrm{Al}_{2} \mathrm{O}_{3}$ & 36 & 92 & 650 \\
\hline
\end{tabular}

Higher NO conversions were obtained for the $2.2 \%$ silver loaded catalyst. In addition, propylene conversions exceeded $90 \%$ for the higher loaded catalysts. This result is ascribed to the fact that SCR reactions compete with the combustion of the reducing agent. Meunier et al. ${ }^{11}$ found that the catalytic activity actually increased slightly after $50 \mathrm{~h}$ at $815 \mathrm{~K}$ with a lower loaded catalyst.

The different tendency of the NO conversion with temperature in comparison to the TPR values for the $0.8 \%$ catalyst is yet not clear. This catalyst presents a lower maximum conversion temperature than the one with $2.2 \%$ silver, in contradiction to the reduction temperatures in the TPR profiles (Figure 3). Moreover, the ethylene conversions follow the TPR values, as expected. It seems here that, for the catalyst with the lowest silver load (smaller particles) the NO reduction reaction occurs before the $\mathrm{C}_{2} \mathrm{H}_{4}$ 
oxidation begins as shown in Figure 5. As explained above, larger particles favor oxygen and propylene adsorption on the same particle. Probably it is more difficult for these two larger molecules to be adsorbed in the $0.8 \% \mathrm{Ag}$ catalyst.

\section{$\mathrm{N}_{2} \mathrm{O}$ production}

The reactions selectivities were estimated by the $\mathrm{N}_{2} \mathrm{O}$ production (Figures 9 and 10). The $\mathrm{N}_{2} \mathrm{O}$ concentration was low $(<6 \%)$ in all the cases studied, indicating high selectivity to $\mathrm{N}_{2}$, which is in accord to the proposed mechanism for selective reduction, where the inorganic ad-NOx species, formed from the interaction of the oxigen with $\mathrm{NO}$, can subsequently produce $\mathrm{N}_{2} \mathrm{O}+\mathrm{N}_{2}$ and/or further react with the reductant or a derived species to form organoNOx compounds as well. In particular, organo-nitro and organo-nitroso compounds and/or their derivatives are suggested to react with $\mathrm{NO}$ or the organo-nitrite to yield $\mathrm{N}_{2} \cdot{ }^{24}$ In general, $\mathrm{N}_{2} \mathrm{O}$ begins to be detected after the NO conversion starts and increases concentration when the NO conversion declines. This behaviour agrees with Meunier and co-workers' ${ }^{25}$ results for silver and cobalt
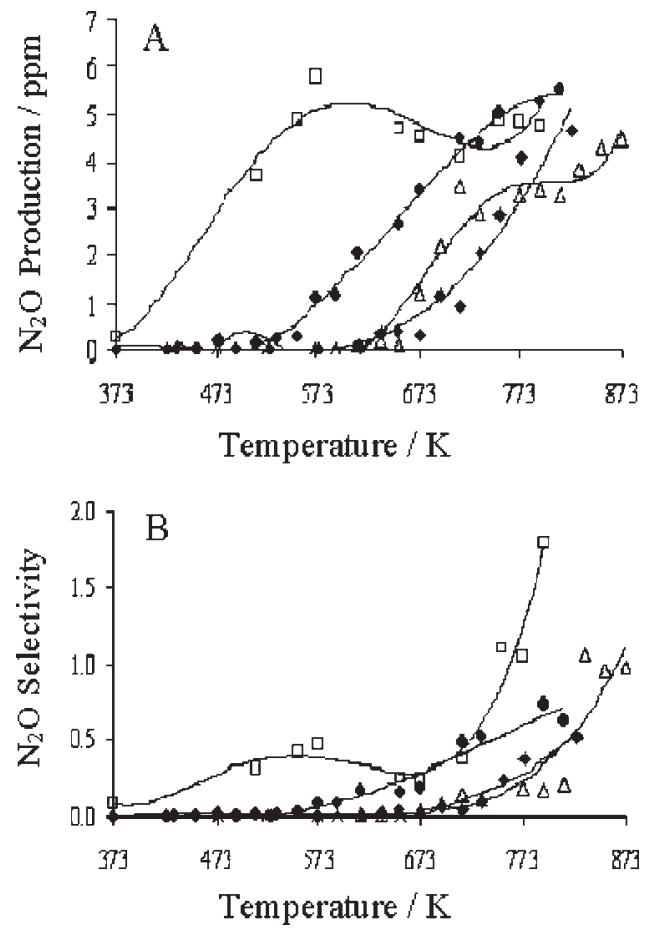

Figure 9. $\mathrm{N}_{2} \mathrm{O}$ production (A) and selectivity (B) vs. temperature

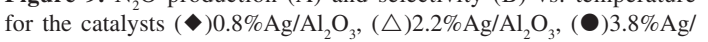
$\mathrm{Al}_{2} \mathrm{O}_{3}$ and $(\square) 7.6 \% \mathrm{Ag} / \mathrm{Al}_{2} \mathrm{O}_{3}$. catalysts. The highest $\mathrm{N}_{2} \mathrm{O}$ production was presented by the $7.6 \% \mathrm{Ag} / \mathrm{Al}_{2} \mathrm{O}_{3}$ catalyst, that had the highest $\mathrm{N}_{2} \mathrm{O}$ production at lower temperature than the one for maximum NO conversion.

The catalysts based on Cordierite presented the lowest $\mathrm{N}_{2} \mathrm{O}$ production, indicating high selectivity to $\mathrm{N}_{2}$.

The $\mathrm{NO}_{2}$ formed could not be quantified with accuracy, since its IR band is overlapped by the ethylene band, as pointed out by others. ${ }^{24}$ Even so, it was possible to estimate that there was $\mathrm{NO}_{2}$ production, especially at the temperature where the $\mathrm{NO}$ conversion was higher. In the catalyst with a silver load of $2.2 \%\left(2.2 \% \mathrm{Ag} / \mathrm{Al}_{2} \mathrm{O}_{3}\right)$ there was a $\mathrm{NO}_{2}$ production of approximately $6 \mathrm{ppm}$, while for the catalyst with a silver load of $7.6 \%\left(7.6 \% \mathrm{Ag} / \mathrm{Al}_{2} \mathrm{O}_{3}\right)$ it reaches 20 ppm, following the same pattern as for $\mathrm{N}_{2} \mathrm{O}$ production.

\section{Conclusions}

The maximum NO conversion temperature was found to be around $673 \mathrm{~K}$ for all the catalysts studied.

The catalysts with silver loads of more than $4 \%$ promoted propylene oxidation reaction in detriment to the NO reduction, indicating that the silver particles were
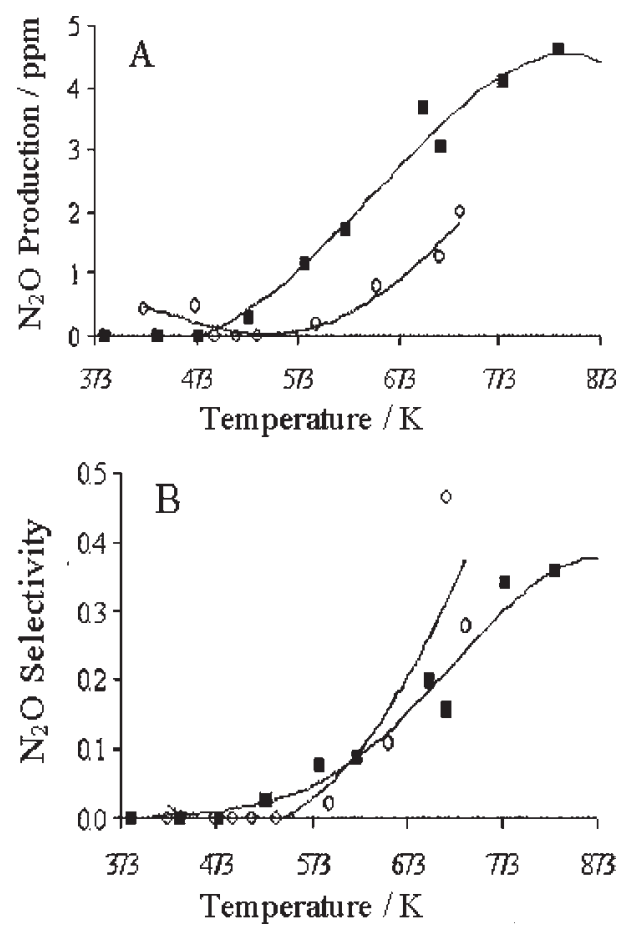

Figure 10. $\mathrm{N}_{2} \mathrm{O}$ production (A) and selectivity (B) vs. temperature for the catalysts $(\mathrm{O}) 0.12 \% \mathrm{Ag} / \mathrm{Al}_{2} \mathrm{O}_{3} /$ Cord and $(\square) 2.5 \% \mathrm{Ag} / \mathrm{Al}_{2} \mathrm{O}_{3}$ / Cord. 
in a reduced state. The higher silver load produced a reduction of the $\mathrm{Ag} / \mathrm{Al}_{2} \mathrm{O}_{3}$ interface owing to the greater diameter of the silver particles, thereby accelerating the propylene oxidation. In addition, the metallic surface area was an important parameter, since a larger area facilitates oxygen and propylene adsorption on the same active site, causing competition with $\mathrm{NO}$ adsorption.

The $\mathrm{Ag} / \mathrm{Al}_{2} \mathrm{O}_{3} /$ Cordierite catalysts promoted hydrocarbon oxidation owing to the larger particle diameters.

The maximum NO conversion temperature was approximately $673 \mathrm{~K}$ and close to the maximum nitrate decompositions temperature, indicating that selective NO reduction involved the formation of surface nitrates.

The two catalysts based on Cordierite showed the lowest $\mathrm{N}_{2} \mathrm{O}$ production and consequently high selectivity to $\mathrm{N}_{2}$.

\section{Acknowledgements}

The authors acknowledge Carlos Gigola (PLAPIQUI, Argentina) for the grateful discussions and the financial support provided by CNPq (Brazil), FAPERGS (Brazil), COPESUL (Brazil).

\section{References}

1. Da Silveira, S.; Gomes, M. G.; Anais Assoc. Bras. Quim. 1997, 46, 242.

2. Farrauto, R. J.; Heck, R. M.; Catal. Today 1999, 51, 351.

3. Park, P. W.; Ragle, C. S.; Boyer, C. L.; Balmer, M. L.; J. Catal. 2002, 210, 97.

4. Burch, R.; Breen, J. P.; Meunier, F. C.; Appl. Catal. B 2002, $1220,1$.

5. Nalven, G. F.; The Environment: Air, Water, and Soil, American Institute of Chemical Engineers, Alche: New York, 1997.

6. Iwamoto, M.; Hamada, H.; Catal. Today 1991, 10, 57.

7. Iwamoto, M.; Yahiro, H.; Catal. Today 1994, 22, 5.
8. Amiridis, M. D.; Zhang, T.; Farrauto, R.; J Appl. Catal. B 1996, 10, 203.

9. Obuchi, A.; Ohi, A.; Nakamura, M.; Ogata, A.; Mizuno, K.; Ohuchi, H.; Appl. Catal. B 1993, 2, 71.

10. Bethke, K. A.; Kung, H. H.; J. Catal. 1997, 172, 93.

11. Meunier, F. C.; Ukropec, R.; Stapleton, C.; Ross, J. R. H.; Appl. Catal. B 2001, 30, 163.

12. Miyadera, T.; Yoshida, K.; Chem. Lett. 1993, 1483.

13. Miyadera, T.; Appl. Catal. B 1993, 2, 199.

14. Agrofiotis, C.; Tsetsekon, A.; J. Eur. Ceram. Soc. 2002, 22, 423.

15. Mao, C. F.; Vannice, M. A.; Appl. Catal. A 1995, 122, 41.

16. Badani, M. V.; Vannice, M. A.; Appl. Catal. A 2000, 204, 129.

17. Shimizu, K-i.; Maeshima, H.; Satsuma, A.; Hattori, T.; Appl. Catal. B 1998, 18, 163.

18. Nakatsuji, T.; Yasukawa, R.; Tabata, K.; Ueda, K.; Niwa, M.; Appl. Catal. B 1998, 17, 333.

19. Vergunst, T.; Kapteijn, F.; Moulijn, J.; Appl. Catal. A 2001, 213, 179.

20. Labhsetwar, N. K.; Watanabe, A.; Biniwale, R. B.; Kumar, R.; Mitsuhashi, T.; Appl. Catal. B 2001, 33, 165.

21. Agrofiotis, C.; Tsetsekon, A.; Stournaras, C. J.; Julbe, A.; Dalmazio, L.; Guizard, C.; Solid State Ionics 2000, 136-137, 1301.

22. Shimizu, K-i.; Shibata, J.; Yoshida, H.; Satsuma, A.; Hattori, T.; Appl. Catal. B 2001, 30, 151.

23. Hoost, T. E.; Kudla, R. J.; Collins, K. M.; Chattha, M. S.; Appl. Catal. B 1997, 13, 59.

24. Meunier, F. C.; Breen, J. P.; Zuzaniuk, V.; Olsson, M.; Ross, R.H.; J. Catal. 1999, 187, 493.

25. Meunier, F. C.; Zuzaniuk, V.; Breen, J. P.; Olsson, M.; Ross, J. R. H.; Catal. Today 2000, 59, 287.

26. Plummer, H. K.; Watkins, W. L. H.; Gandhi, H. S.; Appl. Catal. 1987, 29, 261.

Received: July 17, 2003 Published on the web: July 14, 2004 